\title{
Teaching 4.0 Competency in Higher Learning Institutions: A Systematic Mapping Review
}

\author{
Melor Masdoki, Rosseni Din* and Mohd Effendi @ Ewan Mohd. Matore \\ STEM Enculturation Research Centre \\ Faculty of Education, Universiti Kebangsaan Malaysia, Selangor, Malaysia \\ https://orcid.org/0000-0002-7011-4615 \\ https://orcid.org/0000-0002-0851-9910 \\ https://orcid.org/0000-0002-6369-8501
}

\begin{abstract}
Technology 4.0 has forced the education system to undergo a huge transformation by changing teaching and learning methods. Teaching 4.0 requires teachers to apply varieties of technology used in the teaching and learning process to make it more appealing to new millennials. However, the response to this change has been relatively slow. Consequently, the preparation of effective teaching methods and strategies from educators that can benefit students through learning from differentiated learning styles. Thus, the aim of this study is to collect and extract information from the literature in searching for the research gap, and analyse the most significant studies on the teaching of 4.0 competency in a Higher Learning Institution. The searching process will focus on papers published in journals or presented at specialised international conferences from 2015 until 2021 using a systematic mapping review (SMR). A total of 380 relevant research papers from Scopus, Web of Science, Google Scholars online databases and grey literature were retrieved. Nine final papers were selected in the study. Results from the review showed that the predefined requirement criteria for Teaching 4.0 competencies were not all satisfied in literature. There are limited studies on the Teaching 4.0 competency. Thus, a conceptual framework of measurement for Teaching 4.0 competencies should be developed. It could act as a solution by providing a comprehensive competency measurement and to determine relevant 4.0 competency among Higher Learning Institution educators.
\end{abstract}

Keywords: Technology 4.0; Teaching 4.0; teaching competency; differentiated learning; Higher Learning Institution

*Corresponding author: Rosseni Din, rosseni@ukm.edu.my 


\section{Introduction}

Education 4.0 is defined as the new phase in which Higher Learning Institutions apply a transformation of learning methods and innovative didactic teaching, with intelligent teaching tools and sustainable infrastructures complemented by emerging educational technologies (Miranda \& Molina, 2020). This education transformation has improved the processes of generating knowledge and transferring information (Miranda \& Molina, 2020). The Education 4.0 transformational phase has created a significant change in the education system. It is a change from traditional learning to technology-based learning and aligns with the trend of student learning which characterises education today (Ismail, 2011). Students tend to learn by using numerous modern applications and various means of technology through different kinds of pedagogies such as heutagogy (self-determined learning), paragogy (peer-oriented learning), and cybergogy (virtual-based learning) (Tajudin, 2021). Their readiness towards the fourth industrial revolution technology (Yunos \& Din, 2019), differentiated learning style (Al Mashagbh et al., 2019), and understanding how to personalise their learning (Din, 2015; Din 2016) according to Bloom's taxonomy (Matore, 2021) using a universal design for learning (Din, 2019; Din, 2020a; Din, 2020b) should be considered. The teaching method should be implemented by innovative pedagogical technologies and processes. Teachers play a role as a mentor, reference, and collaborator in transferring the knowledge to students by connecting the teaching and learning with digital transformations and virtualisation procedures. (Miranda et al., 2019; Miranda \& Molina, 2020). More clearly, 21st-century teaching requires teachers to dominate the Industrial Revolution 4.0 by applying various technologies to make the teaching strategy and the transferred of knowledge more appealing to new millennials students known as Teaching 4.0 (Ismail, 2011).

Teaching in Higher Learning Institutions requires creative and effective skills. This is to ensure it will benefit students who learn with differentiated learning styles. In addition, the institutions should ensure educators constantly improve their teaching methods and meet the skills in line with the current educational needs. These are the ways of making sure that the quality of teaching in Higher Learning Institutions will meet the skills requirement and criteria for appointment or promotion and also act as a process of determining the award of outstanding teachers and expert teachers. Studies show that effective teaching methods through the application of technologies and differentiated learning are able to increase the level of competence among educators (Noorashid, 2019). To achieve an excellent level of teaching competence, it needs to be supported by the use of technology as many have reported in previous studies (Barragán-Sánchez et al., 2020; Villarreal-Villa et al., 2019).

\section{Technology in Teaching 4.0}

Teaching 4.0 is the implementation of various technology through academic related supported teaching methodology to produce an active-learning outcome (Prieto et al., 2019). It might also be the use of augmented reality tools in a modular learning system with an interactive virtual model of the equipment (Miranda \& Molina, 2020), cloud computing data, and information processed in real-time 
(Martin et al., 2018). Table 1 identified tools and infrastructures commonly used as technology in Teaching 4.0 (Bonfield et al., 2020; Mourtzis et al., 2017; Golitsynaet al., 2019; Miranda et al., 2019; Miranda \& Molina, 2020; RamírezMontoya et al., 2021; Balakirshnan \& Lay, 2016).

Table 1: Tools and infrastructures of technology in Teaching 4.0

\begin{tabular}{|l|l|}
\hline Technology 4.0 & \multicolumn{1}{c|}{ Tools and Infrastructures } \\
\hline Artificial Intelligence (AI) & $\begin{array}{l}\text { Smart scanner, virtual tutor and facilitator, } \\
\text { virtual class experiment / simulation, } \\
\text { online / real-time assessment }\end{array}$ \\
\hline Robotics & $\begin{array}{l}\text { Simulator machine, electrical and } \\
\text { mechatronics, 3D printers }\end{array}$ \\
\hline Internet of Things (IoT) & $\begin{array}{l}\text { Smart building IoT solutions educational } \\
\text { environments such as school buildings, } \\
\text { classrooms, laboratories, and more. }\end{array}$ \\
\hline Smart Mobile Devices & $\begin{array}{l}\text { Smart phone, tablet, iPad, laptop, notebook, } \\
\text { and electronic textbooks }\end{array}$ \\
\hline $\begin{array}{l}\text { Advance Network Technology \& Web } \\
\text { services }\end{array}$ & $\begin{array}{l}\text { Email, social networks, cloud services, } \\
\text { search engines, gamification }\end{array}$ \\
\hline
\end{tabular}

Adapting multiples technology into Teaching 4.0 effectively impacts on the teaching and learning process. The implementation of these technologies in Higher Learning Institutions are important to ensure that it aligns with the transformation of education. Higher Learning Institutions need to ensure that teachers and lecturers are capable of creatively diversifying teaching innovations using a teaching approach based on the 4.0 elements. These will require teachers to master Teaching 4.0 competencies such as i) digital literacy, ii) critical thinking, iii) problem-solving, iv) competencies in motivation and skills v) self-evaluation, vi) self-efficacy, vii) responsibility, viii) autonomy to teach, and $x$ ) ability to teach effective teaching environment (Ramírez-Montoya et al., 2021). Teachers also should have technological competencies along with good personal characteristics that can guide students with lifelong learning skills (Miranda \& Molina, 2020; Himmetoğlu et al., 2020). A limited study on the combination of all these required skills provide a potential research gap.

Thus, the aim of this paper is to collect and extract information concerning teaching with technologies 4.0 from the literature and searching for the research gap. This include identifying and analysing the most significant studies relating to Teaching 4.0 skills and its contribution towards teaching competency. The studies in existing works on Teaching 4.0 competencies still lack a systematic method. Thus, this paper reports a systematic review of existing works within the scope of the study.

\section{Teaching 4.0 Competencies}

Competence in teaching is very important to ensure that educators provide a teaching method and strategy that can achieve the objectives of a lesson. There are several characteristics of teaching competence as listed by Nessipbayeva (2012): (1) mastery of one or more skills, (2) performance, knowledge, skills, and attitudes that can be assessed and demonstrated, and (3) measurable performance. This 
would summarise how teaching competency is seen as a combination of knowledge, skills, and behaviours applied to improve performance levels and to ensure an individual is qualified or able to perform his role in a given task. It also focuses on the values, qualities, and motivations of an individual who always consistently performs in completing his tasks.

In the context of Teaching 4.0 competency, all characteristics mentioned must align to the use of 4.0 technology. This affects how an individual is able to use his knowledge, skills, behaviors, values, traits and motivation to implement 4.0 technology in his teaching. Indira et. al (2020) suggested that educators should not only act as communicators of knowledge to students but should also prepare themselves to act as knowledge providers in line with technology 4.0. There are four major types of competencies highlighted: (1) educational competence, (2) technologically competence, (3) communicatively competence, and (4) competence counselor (Indira et.al, 2020). Educators need to master technology and must be competent in order to understand problems, including psychological issues, faced by students to use 4.0 technology. Teaching 4.0 plays a big role as an effective teaching method that provides more space for creativity and innovation from educators. Therefore, educators must be prepared to apply various technologies in line with changing trends and the suitability of these to their teaching systems. Teaching 4.0 does not mean an educator must fully utilise technology as a teaching aid but they need to change their way of teaching with differentiated strategies such as self-learning methods, hybrid learning, and virtual learning all adapted to the level of student learning diversity.

\section{Research Methodology}

This study contains three steps recommended by Guzzo et al. (1987) and Egger et al. (1997): (1) the formulation of the problem to be addressed, (2) collection and analysis of the data, and (3) reporting of the results (Egger et al., 1997; Guzzo et al., 1987; Gabarre, 2015; Gabarre et al., 2015; Gabarre et al, 2020). A brief explanation for this is in how the problem may be formulated with the following question: to what extent do recent and respected publications deal with the theme of Teaching 4.0 competency in Higher Learning Institutions? Gabarre (2015) suggested the proposal of several questions that should be identified and then categorized as variables for the studies (Gabarre, 2015). This question can be divided into five different variables: (1) Education 4.0, (2) Teaching 4.0, (3) differentiated learning, (4) teaching competency, and (5) Higher Learning Institutions. These five variables were used to categorise the articles that were selected for SMR and should meet the requirement of recent publications.

\section{Review Process}

Systematic mapping review (SMR) is among the fourteen reviews system that have been used in a significant number of studies by Grant and Booth (2009). According to Maisiri and Van Dyk (2020), this systematic mapping reviews is to identify research gaps in existing literature (Fernandez et al., 2015; Gordon et al., 2012; O'Cathain et al., 2013; McDaniel-Peters \& Wood, 2017; Brett et al., 2011; Booker et al., 2015; Lukersmith et al., 2016). It is a review method commonly used when a focused area of inquiry is in early research development (McDaniel-Peters 
\& Wood, 2017; Maisiri \& Van Dyk, 2020). In comparison, systematic literature review (SLR) identifies, evaluates, interprets, and analyses the available research findings related to formulated research questions, topic areas, or phenomena. The purpose of conducting SLR is to construct a general vision, gather evidence of specific questions. and provide a summary of the literature (Mariano et al., 2017). SLR evaluates the size, scope and quality of the evidence base, while SMR is not primarily concerned with assessing the strength of findings and concluding optimum interventions (Heeb et al., 2020).

This study was aimed at collecting and analysing the most significant studies on the Teaching 4.0 skills and competency in higher learning institution. The type of studies collected were focused on those published in journals or presented at specialised international conferences from 2015 until 2021. After this, relevant information from the literature was extracted in search for the research gap. In order to offer useful tools to promote critical awareness about the areas of research interest and to identify the topics most in need for research, this study has been carried out as a solution in finding the research gap. As reported:

"A systematic mapping study provides an objective procedure for identifying the nature and extent of the research that is available to answer a particular research question. These kinds of studies also help to identify gaps in current research in order to suggest areas for further investigation". (Fernandez et al., 2011)

It is also used to categorized papers selected with sufficient detail in order to answer broad research questions (Miranda \& Molina, 2020).

\section{Systematic Mapping Review (SMR) Search Process}

A predefined search strategy was developed in this study to minimize bias during the search of papers and to find for relevant literature review (Maisiri \& Van Dyk, 2020). The study used five key search terms: Education 4.0, Teaching 4.0, differentiated learning, teaching competencies, and Higher Learning Institutions. The literature search was conducted on three different sources which are Scopus, Web of Science, and Google Scholars online databases and included the search of grey literature on key consulting organisation websites. This is also by expanding the data source by a dedicated search of reference lists (Maisiri \& Van Dyk, 2020; Lukersmith et al., 2016). Table 2 was designed to identify and categorise the keywords which represent factors concerning teaching with technology 4.0

Table 2: Keyword and its requirement

\begin{tabular}{|l|l|}
\hline Keywords (KW) & \multicolumn{1}{|c|}{ Requirements of criteria } \\
\hline Education 4.0 (KW1) & $\begin{array}{l}\text { Existing works that address factors in Education 4.0 or } \\
\text { teaching with technology 4.0 or proposed work using } \\
\text { technology 4.0 in Higher Learning Institution } \\
\text { (Ramírez-Montoya et al., 2021). }\end{array}$ \\
\hline Teaching 4.0 (KW2) & $\begin{array}{l}\text { Papers that propose tools and infrastructures of } \\
\text { technology in Teaching 4.0 including a technique / } \\
\text { approach / model / framework in Higher Learning } \\
\text { Institution (Himmetoğlu et al., 2012; Miranda et al., }\end{array}$ \\
\hline
\end{tabular}




\begin{tabular}{|l|l|}
\hline & $\begin{array}{l}\text { 2019; Miranda \& Molina, 2020; Peredrienko et al., } \\
\text { 2020). }\end{array}$ \\
\hline $\begin{array}{l}\text { Differentiated Learning } \\
\text { (KW3) }\end{array}$ & $\begin{array}{l}\text { It is an instructional approach that accommodates the } \\
\text { diversity of students (abilities, interest, level of } \\
\text { thinking, personalities, demographic background) by } \\
\text { adopting specific teaching strategies, invoking a } \\
\text { variety in learning strategies, assessing individual } \\
\text { needs, and finally pursuing optimal learning outcomes } \\
\text { (Suprayogi \& Valcke, 2016; Suprayogi et al., 2017). }\end{array}$ \\
\hline $\begin{array}{l}\text { Teaching competencies } \\
\text { (KW4) }\end{array}$ & $\begin{array}{l}\text { The level of skills and expertise of lecturers in the use } \\
\text { and application of a variety of technology 4.0 in their } \\
\text { teaching methods either in the classroom or in student } \\
\text { consultation sessions (Jafar et al., 2020; Symanyuk \& } \\
\text { Pecherkina, 2016). }\end{array}$ \\
\hline $\begin{array}{l}\text { Higher Learning Institutions } \\
\text { (KW5) }\end{array}$ & $\begin{array}{l}\text { Public and private universities or colleges (Azizan, } \\
\text { 2020). }\end{array}$ \\
\hline
\end{tabular}

\section{Inclusion and Exclusion Criteria}

Iterative inclusion and exclusion criteria (Maisiri \& Van Dyk, 2020; Shahrol et al., 2020) were conducted to select relevant studies published between 2015 and 2021. The process consists of the following criteria:

1) A collection of papers was reviewed and sorted from the library. Priority is given to published papers from journals and conferences proceeding papers.

2) The papers should at least contain factors concerning teaching with technology 4.0 and the field of study must be related to Education 4.0. The teaching competency models or framework were included.

3) The papers were required to include keywords that attempt to define, propose, suggest, or describe existing works of Education 4.0 and / or in teaching using technology 4.0.

4) For exclusion, papers published older than 2015 were excluded.

5) Papers that do not follow the listed keyword, even if from a related field, were excluded.

6) Papers using the terms teaching competencies loosely in relation to technology 4.0.

\section{Data Analysis}

The data analysis is mainly focused on identifying design requirement gaps in the included mapping review literature (Maisiri \& Van Dyk, 2020). This process was done as measured against the predefined criteria requirements for Teaching 4.0 competencies that has been presented in Table 1. The papers that fulfilled the inclusion and exclusion criteria were short-listed and reviewed for final selection. There are 9 steps of systematic mapping review process as shown in Figure 1 below: 


\section{Systematic Mapping Review}

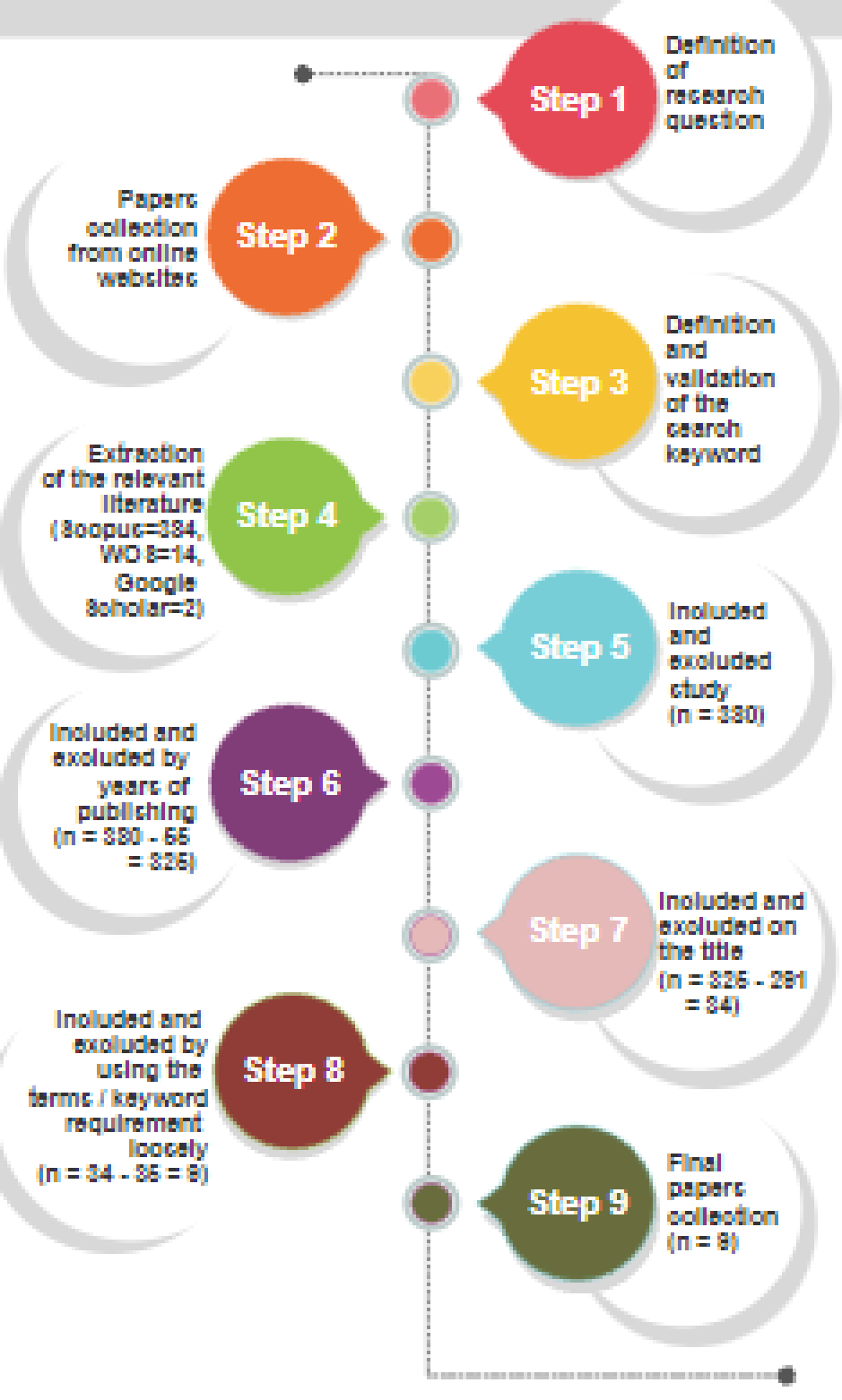

Figure 1: Systematic Mapping Review Process \& Results

The papers that fulfilled the inclusion and exclusion criteria were short-listed and reviewed for final selection.

\section{Result and Discussion}

A brief finding of systematic mapping reviews results and the gap analysis results will be explained in this section. Nine papers were included in the systematic mapping review. The results are as in Table 3: 
Table 3: Gap analysis result

\begin{tabular}{|c|c|c|c|c|c|c|c|c|c|c|}
\hline No & Paper Title \& Reference & Country & $\begin{array}{l}\text { Scopus / } \\
\text { WOS } \\
\text { Journals }\end{array}$ & $\begin{array}{l}\text { Google } \\
\text { Scholar }\end{array}$ & $\begin{array}{l}\text { Refereed } \\
\text { Conference } \\
\text { Proceeding }\end{array}$ & $\begin{array}{l}K \\
W \\
1\end{array}$ & $\begin{array}{l}\mathbf{K} \\
\mathbf{W} \\
\mathbf{2} \\
\end{array}$ & $\begin{array}{l}\mathrm{K} \\
\mathbf{W} \\
\mathbf{3} \\
\end{array}$ & \begin{tabular}{|l|}
$K$ \\
$W$ \\
4 \\
\end{tabular} & $\begin{array}{l}\mathrm{K} \\
\mathbf{W} \\
5\end{array}$ \\
\hline 1 & $\begin{array}{l}\text { Innovations in Education - The } \\
\text { Development of a New } \\
\text { Pedagogical Technology of a } \\
\text { Combinational Type, Focused on } \\
\text { the Development of Personality of } \\
\text { Student (Zhurakovskaya et al., } \\
\text { 2020). }\end{array}$ & Russia & & & & $x$ & $\checkmark$ & $x$ & $x$ & $x$ \\
\hline 2 & $\begin{array}{l}\text { Adapting Universities for } \\
\text { Sustainability Education in } \\
\text { Industry 4.0: Channel of } \\
\text { Challenges and Opportunities } \\
\text { (Mian et al., 2020). }\end{array}$ & $\begin{array}{l}\text { Saudi } \\
\text { Arabia }\end{array}$ & & & & $\checkmark$ & $x$ & $x$ & $x$ & $\checkmark$ \\
\hline 3 & $\begin{array}{l}\text { Teacher Education Institutions in } \\
\text { The Philippines Towards } \\
\text { Education } 4.0 \text { (Alda et al., 2020). }\end{array}$ & Philippines & & & & $\checkmark$ & $x$ & $x$ & $x$ & $\checkmark$ \\
\hline 4 & $\begin{array}{l}\text { Education and Learning } \\
\text { Challenges Based on Information } \\
\text { Technology in the Era of } \\
\text { Industrial Revolution } 4.0 \\
\text { (Syamsuar \& Reflianto, 2018). }\end{array}$ & Indonesia & & & & $\checkmark$ & $x$ & $x$ & $x$ & $\checkmark$ \\
\hline 5 & $\begin{array}{l}\text { The Effect of Cooperative } \\
\text { Learning on the Learning } \\
\text { Approaches of Students with } \\
\text { Different Learning Styles (Colak, } \\
\text { 2015). }\end{array}$ & Turkey & & & & $x$ & $x$ & $\checkmark$ & $\bar{\checkmark}$ & $\checkmark$ \\
\hline 6 & $\begin{array}{l}\text { Driving Education in the Era of } \\
\text { Industrial Revolution 4.0: The } \\
\text { Application of Islamic Values and } \\
\text { Innovation in Teaching in Higher } \\
\text { Learning Institutions (Abdul et } \\
\text { al., 2020). }\end{array}$ & Malaysia & & & & $\checkmark$ & $\checkmark$ & $x$ & $x$ & $\checkmark$ \\
\hline 7 & $\begin{array}{l}\text { The Preparation of Malaysians in } \\
\text { Realizing the Goals of the } \\
\text { Industrial Revolution } 4.0 \text { (Jamhari } \\
\text { et al., 2020). }\end{array}$ & Malaysia & & & & $\checkmark$ & $x$ & $x$ & $x$ & $x$ \\
\hline 8 & $\begin{array}{l}\text { Readiness In Implementing } \\
\text { Teacher Training Programmes } \\
\text { Based on Industrial Revolution } \\
\text { 4.0: Evidence From Malaysian } \\
\text { Public Universities (Saud et al., } \\
\text { 2018). }\end{array}$ & Malaysia & & & & $\checkmark$ & $x$ & $x$ & $x$ & $\checkmark$ \\
\hline 9 & $\begin{array}{l}\text { Students' Learning Styles and } \\
\text { Their Effects on The Use of Social } \\
\text { Media Technology for Learning } \\
\text { (Balakrishnan \& Lay, 2016). }\end{array}$ & Malaysia & & & & $x$ & $x$ & $\checkmark$ & $x$ & $x$ \\
\hline
\end{tabular}


A significant number of Teaching 4.0 competency models and frameworks reviewed in this study focused on skill requirements (Maisiri \& Van Dyk, 2020) in Education 4.0. In Table 3, it can be seen that almost all articles discuss Education 4.0 at the Higher Learning Institutions level. However, only two articles discuss the teaching based on technology 4.0, namely one in Russia and another in Malaysia. Since 2015, more studies have been conducted related to Education 4.0 but there are still relatively few empirical studies examining 4.0 technology-based teaching in depth. Only two studies discussed collaborative learning with various levels of learning skills where one skill was in Higher Learning Institutions. However, these two studies only discuss the use of technology in general and do not specialise in 4.0 technology. There is still a lack of studies that measure and evaluate the level of competence in the use of technology 4.0 specifically among lecturers.

Figure 2 show a total of 9 papers, and as many as $67 \%$ consider the teaching in Higher Learning Institution. Another $67 \%$ or 6 papers deal with Education 4.0. It should be noted that in these in all 6 papers, only 1 paper dealt with teaching with technology 4.0. In this context, the data collected shows that the researchers consider the teaching with technology 4.0 as a new transformational method for carrying out teaching activities. There are a lack of empirical studies assessing the 4.0 teaching skills and expertise. KW2 and KW3 represent 22\% each, while KW3 represents $11 \%$, which shows the existence of limited studies in measuring teaching, differentiated learning, and teaching competencies in regard to technology 4.0.

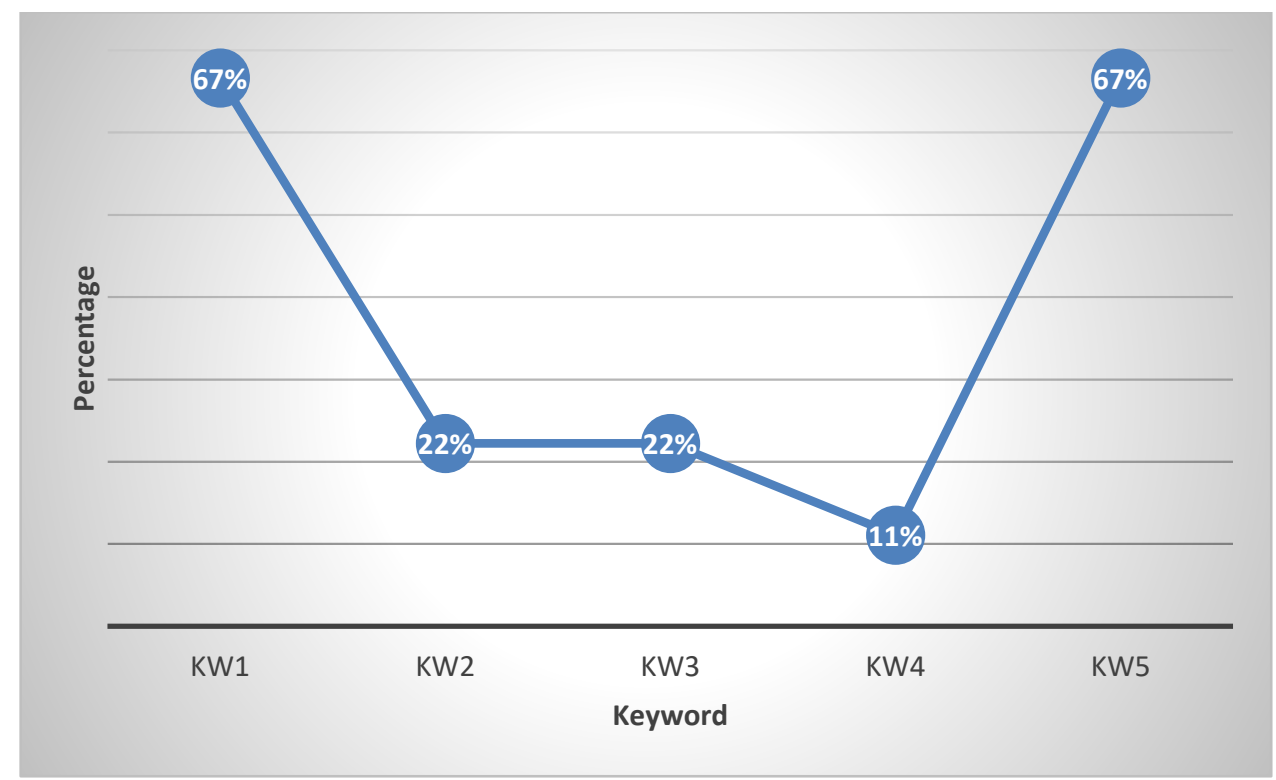

Figure 2: Keywords results by percentage

Overall, literature explained factors concerning Teaching 4.0 in terms of digital literacy, critical thinking, problem-solving skills, and the ability to provide an effective teaching environment. All these factors can be grouped as teaching and learning methods. However, there are no specific factors concerning Teaching 4.0 
and its impact on differentiated learning (KW3). Factors such as responsibility, self-evaluation, self-efficacy, and educator's personal characteristics may contribute to effective teaching delivery and improved teaching competency (KW4). All the factors identified were discussed separately and are yet to be studied as a group of potential variables which contribute to the measurement of Teaching 4.0 competency.

Limited studies concerning Teaching 4.0 and its method of learning provide restricted evidence on how technology 4.0 may contribute to effective and competent teaching strategies. Most studies in Higher Learning Institutions were carried out to assess the readiness of the administrators, educators, and students in adapting 4.0 education transformation. While the majority of studies on the effectiveness of technology were carried out regarding the impact on students and learners. No studies were carried out to assess the level of expertise and competency of educators in implementing technology 4.0 in their teaching process and strategy. Thus, this finding shows that there is a lack of comprehensive Teaching 4.0 assessment tools that address the skills and competency requirements for specific capability functions in Higher Learning Institutions. The reviewed models seldom provided a comparative scale to gauge the competency of teachers or educators with reference to Education 4.0 revolutions. There is a noticeable shortage of studies that can provide empirical studies concerning Teaching 4.0 and its competitiveness. Thus, this result may provide a good research gap for future studies.

\section{Conclusion, research implication and future work}

The scope of this research is to identify and analyse the most significant studies for the Teaching 4.0 competencies in Higher Learning Institutions. The findings prove that there has been limited research done on Teaching 4.0 competency. Thus, this can strengthen the support regarding the importance of building measurement instruments to test and evaluate the skills level of lecturers especially in terms of teaching using technology 4.0 (KW3) and their teaching competency (KW4) in institutions of higher learning (KW5). A conceptual framework of instrument measurement for Teaching 4.0 competencies should be developed.

Besides, the finding also could recommend Higher Learning Institutions to implement policies and provide various training and workshops in encouraging educators to apply technology 4.0 to their teaching processes. It may be important for Higher Learning Institutions to develop Teaching 4.0 competency assessment tools and necessary measurements. Therefore, a valid construction of instruments will facilitate the measurement process and has the potential to help provide empirical evidence that can be used as a reference for future studies.

\section{Acknowledgements}

Our utmost appreciation goes to all those who supported our study, especially to Faculty of Education and the STEM Enculturation Research Centre for Futuristik (GG-2021-014) and STEM \& Minda (GG-2021-002) grants. We are thankful for Dana Pecutan Penerbitan 2021 to support our publication. We would also like to 
thanks to all researchers under the Personalized Education Research Group for financial, intellectual, spiritual, and moral support.

\section{References}

Abdul K. A, Othman, M. K. B. H., \& Saidon, M. K. B. (2020). Driving Education in the Era of Industrial Revolution 4.0: The Application of Islamic Values and Innovation in Teaching in Institutions of Higher Learning", Islāmiyyāt, 42(0), 13-20. https://ejournal.ukm.my/islamiyyat/article/view/40592

Alda, R., Helen, B., \& Dayagbil, F. (2020). Teacher Education Institutions in the Philippines towards Education 4.0. International Journal of Learning, Teaching and Educational Research, (19). https://doi.org/10.26803/ijlter

Al Mashagbh, A., Din, R., Nasir, M. M. K, Halim, L., \& Al-Batainah, R. A. (2019). Reliability and Validity of Online Individualized Multimedia Instruction Instrument for Engineering Communication Skills. Creative Education, 10(12), 3041-3048. https://doi.org /10.4236/ce.2019.1012228

Ana, B. M., Javier, J. M., Lucia, M., \& Raimundo, A. R. (2020). Digital Competence And University Teachers' Conceptions About Teaching. A Structural Causal Model. Sustainability (Switzerland), 12(12). https://www.mdpi.com/2071$1050 / 12 / 12 / 4842 / \mathrm{pdf}$

Azizan, F. Z. (2020). Blended Learning in Higher Education Institution in Malaysia. Proceedings of Regional Conference on Knowledge Integration in ICT, 454-466. http://ldms.oum.edu.my/oumlib/sites/default/files/file_attachments/odlresources/4334/blended-learning.pdf

Balakrishnan, V., \& Lay, G. C. (2016). Students' learning styles and their effects on the use of social media technology for learning. Telematics and Informatics, 33(3), 808-821. https:// doi.org/10.1016/j.tele.2015.12.004.

Barragán-Sánchez, R., Corujo-Vélez, M. C., Palacios-Rodríguez, A., \& Román-Graván, P. (2020). Teaching Digital Competence And Eco-Responsible Use Of Technologies: Development And Validation Of A Scale. Sustainability (Switzerland), 12(18). https://doi.org/10.3390/su12187721

Bonfield, C. A., Salter, M., Longmuir, A., Benson, M., \& Adachi, C. (2020). Transformation or Evolution?: Education 4.0, Teaching and Learning in the Digital Age. Higher Education Pedagogies, 5(1), 223-246. https://doi.org/10.1080/23752696.2020.1816847

Booker, M. J., Shaw, A. R. G., \& Purdy, S. (2015). Why do Patients with 'Primary Care Sensitive' Problems Access Ambulance Services? A Systematic Mapping Review of the Literature. BMJ Open, https://onlinelibrary.wiley.com/doi/10.1111/acem.13220

Brett, J., Staniszewska, S. Newburn, M., Jones, N., \& Taylor, L. (2011). A systematic mapping review of effective interventions for communicating with, supporting and providing information to parents of preterm infants. BMJ Open, (1). https://doi.org/10.1136/bmjopen-2010-000023

Cecilia, W. P., Li-Tsang, Pluto, K.K., Choi, Sinclair, K., \& Wong, R. S. M. (2009). An Explorative Study of an Emerging Practice Clinical Education Programme for Occupational Therapy Students. Hong Kong Journal of Occupational Therapy, 19, 4449. https:// doi.org/10.1016/S1569-1861(10)70003-6

Çolak, E. (2015). The effect of cooperative learning on the learning approaches of students with different learning styles. Eurasian Journal of Educational Research, 59, 17-34. https://files.eric.ed.gov/fulltext/EJ1070614.pdf 
Din, R. (2015). Forward from the Chief Editor," Journal of Personalized Learning, 1(1), 1-3. http://spaj.ukm.my/jplearning/index.php/jplearning/article/view/27

Din, R. (2016). Notes from the Chief Editor: On Designing Personalized Learning, Journal of Personalized Learning, 2(1), 1-3. http://spaj.ukm.my/jplearning/index.php/jplearning/article/view/108

Din, R. (2019, August 20-22). Partial Least Square Structural Equation Modeling in The Final Phase of Product and Instrument Development using Universal Design and Agile Development Model. 11th International Conference of Numerical Analysis in Engineering (NAE) (pp. 40-41). Hotel Bangi Putrajaya, Selangor.

Din, R. (2020a). Partial Least Square Structural Equation Modelling in the Final Phase of Product and Instrument Development using Universal Design and Agile Development Model. Jurnal Kejuruteraan SI, 3(1), 103-109. https://doi.org/10.17576/jkukm-2020-si3(1)-16

Din, R. (2020b). Notes from the Chief Editor: On Universal Design and Agile Development. Journal of Personalized Learning, 3(1), 1-7. http://spaj.ukm.my/jplearning/index.php/jplearning/article/download/145/ 95

Egger, M., Smith, G. D., \& Phillips, A. N. (1997). Meta-analysis: Principles and Procedures. British Medical Journal. 315(7121), 1533-1537. https://www.bmj.com/content/315/7121/1533.full

Fernandez, A., Insfran, E., \& Abrahão, S. (2011). Usability evaluation methods for the web: a systematic mapping study. Inf. Softw. Technol., 53(8), 789-817. https://doi.org/10.1016/j.infsof.2011.02.007

Fernandez, A., Black, J., Jones, M., Wilson, L., Salvador-Carulla, L., Astell-Burt, T., \& Black, D. (2015). Flooding and Mental Health: A Systematic Mapping Review, PLoS ONE, 10(4). https://doi.org/10.1371/journal.pone.0119929

Gabarre, S. (2015). Foreign Language Learning Through Ubiquitous Mobile Social Networking [Ph.D thesis, Universiti Kebangsaan Malaysia].

Gabarre, S., Gabarre, C., Din, R., Shah, P. M., \& Abdul Karim, A. (2015). Mobile Assisted Social Networking Langauge Learning. Journal of Personalized Learning. http://spaj.ukm.my/jplearning/index.php/jplearning/article/view/15

Serge, G., Cecile, G., \& Rosseni, D. (2020). A Methodological Guide to Systematic Qualitative Research. Bangi: Penerbit UKM.

Golitsyna, I. N., Eminov, F. I., \& Eminov, B. F. (2019). Education 4.0 in teaching/learning strategies. Proceedings - International Conference on Developments in ESystems Engineering, DeSE, October-20, 205-208. https://doi.org/10.25046/aj060254

Gordon, A. L., Logan, P. A., Jones, R. G., Forrester-Paton, C., Mamo, J.P., \& Gladman, J. R. F. (2012). A Systematic Mapping Review of Randomized Controlled Trials (RCTs) in Care Homes, BMC Geriatrics, 12(31). http://creativecommons.org/licenses/by/2.0/

Grant, M. J., \& Booth, A. (2009). A Typology of Reviews: An Analysis of 14 Review Types and Associated Methodologies. Health Information \& Libraries Journal, 26(2), 91-108. http://doi.org/10.1111/j.1471-1842.2009.00848.x

Guzzo, R. A., Jackson, S. E., \& Katzell, R. A. (1987). Meta-analysis analysis. Research in Organizational Behavior, 9, 407-442. https://www.researchgate.net/publication/232496069_Meta-analysis_analysis

Himmetoğlu, B., Ayduğ, D., \& Bayrak, C. (2020). Education 4.0: Defining the teacher, the student, and the school manager aspects of the revolution. Turkish Online Journal of Distance Education, 21, 12-28. https://doi.org/10.17718/tojde.770896 
Heeb, R., Hooper, B., \& Taff, S. (2020). Representation of Theory in Occupational Therapy Education: An International Systematic Mapping Review 1940 - 2015. Journal of Occupational Theraphy Education, 4(4). https://doi.org/10.26681/jote.2020.040401

Indira, E., Hermanto, A., \& Pramono, S. (2020). Improvement of Teacher Competence in the Industrial Revolution Era 4.0. International Conference on Science and Education and Technology (ISET). https://doi.org/10.2991/assehr.k.200620.068

Ismail, W. C. N. (2011). Lecturer's Teaching Style, Learning Style, Participation Motive and Student Satisfaction Level in Non-Formal Education Program in KPTM Community Colleges. Universiti Kebangsaan Malaysia.

Jafar, D. S. A., Saud, M. S., Hamid, M. Z. A., Suhairom, N., Hisham, M. H. M., \& Zaid, Y. H. (2020). Tvet Teacher Professional Competency Framework In Industry 4.0 Era, 8(5), 1969-1979. https:// doi.org/10.13189/ujer.2020.080534

Jamhari, A. A., Abd., R., Sit,i H., Karim, M., Nur, A., Mohd, I., \& Mohamad, I. (2020). The preparation of Malaysians in realizing the goals of the 4.0 industrial revolution. Malaysian Journal of Social Sciences and Humanities (MJSSH), 5(10), 75-82. https://eprints.utm.my/id/eprint/view/subjects/H1.html

Lukersmith, S., Millington, M., \& Salvador-Carulla, L. (2016). What is case management? A Scopping and Mapping Review. International Journal of Integrated Care, 16(4), 113. http://doi.org/10.5334/ijic.2477

Maisiri, W., \& Van Dyk, L. (2020). Industry 4.0 Competence Maturity Model Design Requirements: A Systematic Mapping Review. 2020 IFEES World Engineering Education Forum - Global Engineering Deans Council (WEEF-GEDC), 1-6. https://doi.org/10.1109/WEEF-GEDC49885.2020.9293654

Mariano, D.C. B., Leite, C., Santos, L.H.S., Rocha, R. E. O., \& Melo-Minardi, R. C. (2017). A Guide to Performing Systematic Literature Reviews in Bioinformatics. arXiv: Quantitatve Methods, 1, 92-100. https://arxiv.org/abs/1707.05813

Martin, J., Bohuslava, J., \& Igor, H. (2018). Augmented reality in Education 4.0. In Proceedings of the IEEE 13th International Scientific and Technical Conference on Computer Sciences and Information Technologies (CSIT), 1, 231-236. https://doi.org/10.1109/STC-CSIT.2018.8526676

Matore, M. E. E. M. (2021). Rasch Model Assessment for Bloom Digital Taxonomy Applications. Computers, Materials \& Continua, 68(1), 1235-1253. https://doi.org/10.32604/cmc.2021.016143

McDaniel-Peters, B. C., \& Wood, W. (2017). Autism and equine-assisted interventions: A systematic mapping review. Journal of Autism and Developmental Disorders, 47(10), 3220-3242.

https://www.sciencedirect.com/science/article/pii/S1750946720301859

Mian, S. H., Salah, B., Ameen, W., Moiduddin, K., \& Alkhalefah, H. (2020). Adapting Universities for Sustainability Education in Industry 4.0: Channel of Challenges and Opportunities. Sustainability, 12(15), 6100. http://dx.doi.org/10.3390/su12156100

Miranda, J., López, C. S., Navarro, S., Bustamante, M. R., Molina, J. M., \& Molina, A. (2019). Open Innovation Laboratories as Enabling Resources to Reach the Vision of Education 4.0. In Proceedings of the 2019 IEEE International Conference on Engineering, Technology and Innovation (ICE/ITMC), 1-7. https://doi.org/10.1109/ICE.2019.8792595

Miranda, J., \& Molina, A. (2020). Designing Hybrid Learning Programs in Higher Education by Applying Education 4.0: The Innovation Challenge Bootcamp as 
Case Study. In Proceedings of the 2020 IEEE Learning with MOOCS (LWMOOCS), 31-36. https://www.mdpi.com/2071-1050/13/11/5768/htm

Mourtzis, D., Vlachou, E., Dimitrakopoulos, G., \& Zogopoulos, V. (2017). Cyber- Physical Systems and Education 4.0 - The Teaching Factory 4.0 Concept. Procedia Manufacturing, 23, 129-134.

Nessipbayeva, O. (2012). The Competencies of the Modern Teacher. Paper presented at the Annual Meeting of the Bulgarian Comparative Education Society, 7.

Noorashid, N. A. (2019). Industrial Revolution 4.0: Impact on the Development of Higher Education in Malaysia. Journal Of Science And Management Research, 55-67. https://widad.edu.my/download.php?f=Journal_Vol5_Nov2019_04.pdf

O'Cathain, A, Thomas, K. J., Drabble, S. J., Rudolph, A., \& Hewison, J. (2013). What can qualitative research do for randomised controlled trials? A systematic mapping review. BMJ Open, 3(6). http://dx.doi.org/10.1136/bmjopen-2013-002889

Peredrienko, T., Oxana, B., \& Yaroslavova, E. (2020). New Language Learning Environment: Employers' - Learners' Expectations and the Role of Teacher 4.0. International Journal of Instruction, 13, 105-118. https://doi.org/10.29333/iji.2020.1338a.

Prieto, M. D., Sobrino, Á. F., Soto, L. R., Romero, D., Biosca P. F., \& Martínez, L. R. (2019). Active Learning-based Laboratory towards Engineering Education 4.0. In Proceedings of the 24th IEEE International Conference on Emerging Technologies and Factory Automation (ETFA), 776-783. https://www.mdpi.com/19995903/13/8/193/htm

Ramírez-Montoya, M. S., Loaiza-Aguirre, M. I., Zúñiga-Ojeda, A., \& Portuguez-Castro, M. (2021). Characterization of the teaching profile within the framework of education 4.0. Future Internet, 13(4), 1-17. https://doi.org/10.3390/fi13040091

Saud, M. S., Rameli, M. R., Kosnin, A. M., Yahaya, N., Kamin, Y., Zakaria, M. A. Z. M., Mokhtar, M., Abdullah, A. H., Suhairom, N., Kamis, A., Rahman, F. A., Minghat, A. D., Daris, Z. M., Alhassora, N. S. A., \& Omar, M. (2018). Readiness In Implementing Teacher Training Programmes Based On Industrial Revolution 4.0: Evidence From Malaysian Public Universities. Journal Of Engineering Science And Technology, 13, 42-48.

Scalera, M., Gentile, E., Plantamura, P., \& Dimauro, G. (2020). A Systematic Mapping Study in Cloud for Educational Innovation. Applied Sciences. 10, 4531. https://doi.org/10.3390/app10134531

Shahrol, S. J. M., Sulaiman, S., Samingan, M. R., \& Mohamed, H. (2020). A Systematic Literature Review on Teaching and Learning English Using Mobile Technology. International Journal of Information and Education Technology, 10(9), 709714. https://doi.org/10.18178/ijiet.2020.10.9.1447

Soenarto, S., Sugito, Suyanta, Siswantoyo, \& Marwanti. (2020). Vocational And Senior High School Professional Teachers In Industry 4.0. Education Horizon, 39(3), 655665. https:// doi.org/10.21831/cp.v39i3.32926

Suprayogi, M. N., \& Valcke, M. (2016). Differentiated instruction in primary schools: Implementation and challenges in Indonesia. PONTE, 72(6), 2-18. https:// biblio.ugent.be/publication/7249942

Suprayogi, M. N., Valcke, M., \& Godwin, R. (2017). Teachers and their implementation of differentiated instruction in the classroom. Teaching and Teacher Education, 67, 291301. https:// biblio.ugent.be/publication/8526487 
Syamsuar \& Reflianto, (2018). Education and Learning Challenges based on Information Technology in the Era of Industrial Revolution 4.0. Scientific Journal of Educational Technology, 6(2), 1-13. https://doi.org/10.24036/et.v2i2.101343

Symanyuk, E. E., \& Pecherkina, A. A. (2016). A Study on The Components of Teachers' Professional Competence. New Educational Review, 44(2), 198-210. https:// doi.org/10.15804/tner.2016.44.2.16

Tajudin, M. N., Suhaimi, N. A., Adnan, M., \& Puteh, M. (2021). Promoting Transformative Mathematical Learning Through Heutagogy, Paragogy and Cybergogy Approaches. PalArch's Journal of Archaeology of Egypt/ Egyptology, (17), 481-497. https://www.researchgate.net/publication/348190338

Villarreal-Villa, S., García-Guliany, J., Hernández-Palma, H., \& Steffens-Sanabria, E. (2019). Teacher Competences And Transformations In Education In The Digital Age. Formacion Universitaria, 12(6), 3-14. https://doi.org/10.4067/S071850062019000600003

Wendler, R. (2012). The maturity of maturity model research: a systematic mapping study. Inf. Softw. Technol. 54(12), 1317-1339. https://dl.acm.org/doi/10.1016/j.infsof.2015.03.007

Yunos, S., \& Din, R. (2019). The Generation Z Readiness for Industrial Revolution 4.0. Creative Education, 10, 2993-3002. https://doi.org/10.4236/ce.2019.1012223

Zhurakovskaya, V., Sichinava, A., Simakova, T., Olicheva, O., Rykov, S., Valeeva, J., Kulachinskaya, A., et al. (2020). Innovations in Education - The Development of a New Pedagogical Technology of a Combinational Type, Focused on the Development of Personality of Students. Journal of Open Innovation: Technology, Market, and Complexity, 6(4), 123. https://doi.org /10.3390/joitmc6040123 